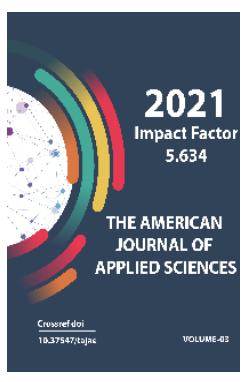

Journal Website: http://usajournalshub.c om/index,php/tajas

Copyright: Original content from this work may be used under the terms of the creative commons attributes 4.0 licence.

\section{The Relationship Between Psychological Well-Being And Quality Of Life Management And The Quality Of Human Capital}

\author{
Vasilina Vladimirovna Krutikova \\ Master's Degree Student,(Technological University), Korolev, Russian Federation \\ Erkin Tuychiyevich Khakimov \\ Candidate Of Philosophical Sciences, Associate Professor, Ferghana State University, \\ Uzbekistan
}

\title{
ABSTRACT
}

The article deals with the problem of psychological well-being in relation to the management of the quality of life and the quality of human capital development as an effect of managing these mutually conditioned processes, as a goal and means of managing the quality of life and the quality of human capital.

\section{KEYWORDS}

Psychological well-being, quality of life, human capital, quality of life management, human capital management, structure of human capital, structure of quality of life, components of psychological well-being.

\section{INTRODUCTION}

Managing the quality of human capital development is associated with the problem of the quality of life of both society as a whole and an individual and, accordingly, ultimately, with the problem of psychological well-being of people. The issues of effective management of the quality of human capital, the quality of life and psychological well-being as interrelated are actualized by the development of the market economy and new ontological realities 
of social life. The categories of "quality of life" and "human capital" as scientific terms first appeared in the 50-60s of the XX century. in the USA and, which is significant, almost simultaneously. They reflect the general nature of human existence, because of this there is a deep ontological relationship between them, which manifests itself in their fullness with a diverse socio-economic content associated with various aspects of the reproduction process, which has not yet received sufficient attention in the studies of both Russian and Uzbek scientists. ... These categories reflect the essential characteristics of the market structure of society, its potential for creating the necessary well-being in society.

The credit for the advancement of the concept of human capital belongs to the famous American economist, Nobel laureate Theodore Schultz, and the basic theoretical model was developed in the book by Gary Becker (also Nobel laureate) Human Capital (first edition 1964). This book became the basis for all subsequent research in this area and was recognized as a classic of modern economics.

\section{MATERIALS AND METHODS}

The works of the classics of economic theory A. Smith, D. Ricardo, A. Marshall, K. Marx are devoted to the study of the general methodological aspects of the problem of "human capital". They consistently worked out the methodological principles of economic theory, which made it possible to further consider the immaterial elements of production as objects of a capital nature.

The theory of human capital was developed in the works of G. Becker, I. Ben-Porat, M. Blaug, W. Bowen, M. Woodhall, S. Daisy, J. Jones, B.
Kicker, J. Mintzer, R. Layard, G. .Psakharopoulos, M. Karnoy, F. Mahlup, L. Hansen. Studies by E. Denison, J. Kendrick, T. Schultz, P. Romer, R. Lucas are devoted to the study of human capital as a factor of economic growth.

Social issues associated with the concept of efficiency and equity, private and social benefits of education, the causes of social inequality were reflected in the works of $\mathrm{N}$. Barr, J. Weisy, B. Weisbrod, W. McMegon, S. Bowles, L. Lawrow, M. Spence, K. Arrow.

It should be noted that the concept of human capital is also used for assessing national wealth, developed by the World Bank. In this interpretation, national wealth includes natural, reproductive and human capital. In the structure of the national wealth calculated in this way, human capital dominates, accounting for about $2 / 3$ of its final assessment, and in the countries of North and Central America, Western Europe and East Asia, it reaches 3/4 of the total value of national wealth. Based on this model, human capital began to be considered the main factor of social reproduction at the end of the zoth century.

\section{THE MAIN PART}

The competitiveness and leadership of the economy as a whole, of an individual enterprise and a person in the current situation are largely determined by the quality of human capital development - the professionalism of workers. American scientist E. Toffler noted that human capital is a measure in a person to generate income. Human capital includes innate ability and talent, as well as education and acquired qualifications. Human capital, in fact, is an integral resource and is a combination of 
health capitals, professional knowledge, skills, intellectual, organizational, cultural and moral, brand capital, formed as a result of activities aimed at personal and professional development of an individual in order to maximize the benefits they bring to society and the growth of their own income. [4] Human capital includes, in addition to knowledge and practical experience, human health and motivation, intellectual abilities, psychological, ideological and cultural-historical properties of the individual. [7, p. 48-49] According to N.E. Simonovich, human capital can be represented as a set of certain factors:

- Human condition: intelligence, energy, reliability, dedication.

- Ability to learn: giftedness, genius, quick thinking, creativity.

- Ability to teach others: the formation of goals for subordinates and colleagues, develop a team spirit and a system of values, ensure good social well-being of the individual in the team and in the family. [8, p.143].

The following components can be distinguished in human capital: quality of life as the most important and fixed capital; human knowledge; intellectual capital, which includes knowledge, practical skills, creative and thinking abilities of people, moral and ethical values; emotional capital, which is inherently the main driving force behind human actions and behavior [9].

Professor of the Department of Political Psychology of St. Petersburg State University Yuryev A.I., based on the method of the systematic approach of Professor V.A. Hansen, developed the concept of human capital. In his opinion, human capital is the quantity and quality of people who are suitable for the competitive struggle in terms of their medical indicators, psychological, intellectual, cultural, and professional parameters. Human capital has four basic psychological capacities: vitality, performance, innovation, and learning. These four basic abilities cover all the requirements for a person and human capital from a practical point of view. All other psychological properties and characteristics are special cases of these abilities [6].

The influence of vocational training on labor productivity has been sufficiently studied. The issues of the influence of the sociopsychological development of human capital on the quality and productivity of labor have not been given sufficient attention in the scientific literature. According to foreign scientists, the priority issue for business in the current situation is the question of finding the most talented, psychologically stable, communicative, effective workers [2]. The level of social and psychological development of an employee in a modern situation is as important as his professional skills. Social and psychological development of a person is characterized by the level of communication skills, the ability to manage their emotions, attitude towards life and personal time management [10].

The interpretation of human capital, despite the complexity of its structure, is more definite, the understanding of the category of quality of life as broader and more flexible, assumes, according to UN experts, the use of up to 200 indicators. The idea of the quality of life depends on many factors, including the age of the person. For example, for older people, modern technologies are not as necessary and important as for young people. This is due to 
the fact that, due to their age, the majority of the elderly are not so easily and not fully able to master new computer technologies, despite the fact that the modern world is difficult to imagine without the global Internet, which many people need today for a comfortable life. Let's take, for example, the electronic registration system being introduced in polyclinics in Uzbekistan. In order to get to a doctor, you need to go to the site and register by entering the necessary data, choosing the right doctor and a convenient time to visit. For young people who own modern technologies, everything is very simple and convenient making an appointment with a doctor is not difficult, but for an elderly person who is poorly versed in gadgets, this process can be quite complicated, causing certain difficulties, and an untimely visit to a doctor can complicate the course illness of an elderly patient and lead to undesirable consequences. The example with electronic registration indicates that for different age groups of people, the content of the category of quality of life will be understood depending on their social, professional status, moral and psychological state and, of course, on the state policy in this matter.

Improving the quality of life of young people as the future of any state is one of the urgent problems. The launch and implementation of certain state programs involves taking into account the needs of young people. According to research data, there are a number of negative trends characteristic of the formation of the modern youth population: its reduction as a labor resource of the country; a certain social, medico-biological and psychological deformation of the quality of the future economically active population [5].
As a result of a survey of bachelors, masters and postgraduates of a number of universities in the Fergana region of Uzbekistan (50 people), five main markers of the quality of life were identified that arouse the greatest interest among young people. The category "Low wages" was especially significant for young people, receiving $42 \%$ of the respondents' votes, then - "Lifestyle" - 40\%, "Corruption" - 36\%, "Employment after obtaining a specialty" - $28 \%$ and the category "High prices" with $24 \%$ of the vote. The analysis of the results of the survey revealed the activity of students and their interest in the problem of the quality of life. Young people differ significantly from other age groups: they are a part of society that has an accelerated process of adaptation, greater social mobility, accelerated growth of material needs, which is associated with the need to form their living space. Because of this, the "quality of life of young people" is an integral concept that characterizes the aspects of their life and the completeness of satisfying the entire range of needs and interests of a given age category of people. Young people are not homogeneous in terms of their social composition: differences are determined by age, place of residence, nature of employment, worldview, and lifestyle. Student youth, undoubtedly, are less independent in the possibility of regulating the conditions of the quality of life and, therefore, their assessment of the quality of life has its own certain specific elements. The survey showed that there is a very broad and heterogeneous structure of opinions. The needs of young people and older people have a number of differences, as a result of which it can be assumed that the assessment of the degree of importance of the elements of the quality of life has certain differences in different age groups. 
In the post-industrial era, the development of human civilization brought the problem of the quality of life to the forefront, as a result of which the category of quality acquired a system-forming character. The relevance of these interrelated problems is determined by the steady interest in them of a wide range of researchers both abroad, and in Russia, and in Uzbekistan. The issue of the quality of life and, as a consequence, psychological well-being is one of the priorities in the context of the reforms being carried out in the Uzbek economy. For a number of objective and subjective reasons, the standard of living in Uzbekistan in many respects still lags behind the standard of living in more developed countries, therefore, various projects are being implemented in Uzbekistan with the help of UNDP. According to the UNDP Resident Representative and UN Resident Coordinator in Uzbekistan A. Nirodi, the implementation of more than 40 projects envisaged by the UN Development Program is an important partner for the country's government and a key player among international development organizations. Analytical advice and technical support are provided in three interrelated areas: economic (sustainable) development and improving human well-being, good governance and environmental protection. In addition, this international organization helps the implementation of projects of other major donors - the European Union, the World Bank, the Asian Development Bank. For example, a joint project "Improving Living Standards" is being implemented with the EU, thanks to which 75,000 people in rural areas have already received improved access to health services. Approximately 52 thousand residents want gas. More than 20 thousand people use clean tap water. The lives of over a thousand families are improved through microfinance programs [1].

Obviously, in modern conditions, economic and political stability in society is largely determined by the solution to the problem of the quality of life of the population, the dynamics of the standard of living and the factors that determine it, including such a component as psychological well-being. The direction and pace of further transformations in the country, the progressive, sustainable and balanced development of both Russian and Uzbek society, depend on the solution of this problem. The problem of improving the level and quality of life is also relevant for modern Uzbekistan, as a result of which the category of quality plays the role of an integral characteristic of the socio-economic system and is necessarily associated with the psychological well-being of people. It is obvious that improving the quality of life as a strategy and tactics for the development of the state presupposes joint efforts of both an individual and society as a whole.

Over the past two decades, the content of the concept of "quality" has significantly changed and expanded: the content of the problem "quality of goods and labor" was transformed into the problems of "quality of culture", "quality of education", "quality of man and human capital". The defining moment in this process was the transition from the functioning of profit as the main criterion of economic development to the functioning of the quality of life as the main criterion, which also includes such indicators as the quality of the living environment, the level of material well-being, the degree of spiritual development and psychological well-being. According to modern scientists - economists 
and politicians, the XXI century is the century of quality: the quality of life is considered in the international community as the main indicator characterizing the level of the country's development.

It should be emphasized that the category "quality of life" is still not clearly defined. In accordance with the UN Development Program, the main indicators characterizing the quality of life are: 1) life expectancy; 2) education; 3) the level of GDP per capita.

It can be argued that the quality of life is a complex integral category that includes all the conditions of existence necessary for the individual, the level of development and the degree of satisfaction of the entire complex of needs and interests of people, their psychological well-being. It also includes, as important components, goods and services, income, savings, spiritual needs, personal safety and other attributes of social comfort, as well as the state of the environment. Obviously, the quality of life is the modern paradigm of civilizational development.

The category "quality of life" is necessary to understand the level of completeness of satisfaction of the growing needs and desires of people, it manifests itself in various forms of life. It should be noted that the quality of life includes the standard of living together with the quality of the environment, determining the basic conditions of the social climate, psychological comfort and wealth of human life. At the same time, it is important to emphasize that the subjective intellectual process forms in each person the satisfaction of a special property - self-identification, which creates his own individual quality of life. Modern post-industrial requirements determine that a person's status is directly determined by his intellect, education and health, which allow accumulating human capital [3].

It is customary to single out the following indicators as the basic components of psychological well-being:

- Self-acceptance (positive assessment of yourself and your life);

- The presence of goals that give direction and meaning to life;

- Personal growth as a sense of continuous development and self-realization;

- Competence (control over the environment, the ability to effectively manage your life);

- Autonomy (the ability to follow your own beliefs;

- Positive relationships with others.

Psychological well-being is closely related to concepts such as mental health and meaningfulness in life. As noted by P.P. Fesenko, the studies existing in personality psychology do not give an unambiguous answer to this question, however, based on his own research, the author claims that the meaningfulness of life and the psychological well-being of the individual directly and significantly correlate with each other. According to his data, all structural components of psychological well-being are directly correlated with the level of meaningfulness in life and life orientations.

It can be assumed that the level of psychological well-being will correspond to meeting the needs of different levels:

1) Vital (biological) needs; 
2) Social needs - the desire to belong to a social group (community) and to occupy a certain place in this group, to enjoy the affection and attention of others, to be an object of their respect and love;

3) Ideal needs for cognition of the surrounding world and one's place in it, cognition of the meaning and purpose of one's existence on earth, both by appropriating existing cultural values and by discovering a completely new one, unknown to previous generations.

\section{CONCLUSION}

The category of psychological well-being is an insufficiently studied psychological reality in the context of the quality of life and the management of the development of the quality of human capital. It should be noted that her understanding is the interconnection of objective and subjective moments as a reflection of feelings, experience, perceptions of people different in age, status, professions, values and needs. It can be assumed that psychological well-being is able to play the role of a battery that "strikes a spark" to launch the activity of labor and other types of activity, providing the rise of vital and creative forces. Unwellness makes a person vulnerable to illness, mental illness, displacement from society and life. Psychological well-being can be represented as an integral indicator, formed by the following differential experiences: as 1) an individual experiencing great satisfaction and happiness; 2) a person who has faith in himself and the truth of his life strategy; 3) a subject that creates consumer value by his labor; 4) an individual with understanding and hope as a result of intellectual quest.
Psychological research of human capital can be carried out through testing using psychological blank tests and sociological questionnaires. The empirical data obtained in this case will make it possible to conduct a kind of "audit" of human capital to substantiate various plans social, political and economic, to identify the reasons for the successes and failures of the economy and the development of civil society. Such information is necessary for psychological science, which has given priority in assessing human potential to economics and sociology. Such data make it possible to assess the psychological state of a person and society through indicators of mental state and the structure of mental properties, levels of development of cognitive processes, and not to use the assessment of their states through secondary indicators of consumption obtained by economics and sociology.Such information is necessary for the modernization of the entire system of formation and accumulation of human capital in the systems of upbringing, education, culture, and medicine [6].

It should be noted that psychological wellbeing presupposes internal cultural transformation as a necessary component of the quality of human capital development.

Thus, comparison and analysis of the content of the concepts of "human capital", "quality of life" and "psychological well-being" allows us to conclude that these concepts intersect, if we use the formal logical Euler-Venn schemes, they have more common features than different. At the same time, the linear scheme "management of the development of the quality of human capital - quality of life psychological well-being" can be read and will be correct both from left to right and from right to left, only in the first case the first two 
concepts will be considered as means and conditions for achieving the goal psychological well-being, and in the second the last two - as means and conditions that make it possible to effectively manage the quality of human capital development. There is no doubt that psychological well-being, the quality of life and the quality of human capital are interconnected and condition each other, which must be taken into account in the practice of managing these processes.

\section{REFERENCES}

1. Проекты ПРООН в Узбекистане. http://internet.bibo.kz/307489-proektyproon-v-uzbekistane.html

2. Друкер П.Ф. Менеджмент. Вызовы XXI века. М. Манн, Иванов и Фербер. 2012.

3. Зарецкий А.Д., Иванова Т.Е. Менеджмент воспроизводственной взаимосвязи качества жизни и человеческого капитала. Международный журнал прикладных и фундаментальных исследований. - 2015. - № 5 (часть 3) - C. 468-472 http://appliedresearch.ru/ru/article/view?id=6812

4. Интернет-источник: https://centeryf.ru/data/economy/Kachestvochelovecheskogo-kapitala.php

5. Ложко В.В. Современная модель формирования человеческого капитала и управления качеством жизни и здоровьем населения регионов России. https://cyberleninka.ru/article/n/sovreme nnnaya-model-formirovaniyachelovecheskogo-kapitala-i-upravleniyakachestvom-zhizni-i-zdoroviemnaseleniya-regionov-rossii/viewer

6. Полаева Д. К. Теория психологического измерения человеческого капитала., https://present5.com/teoriya- psixologicheskogo-izmereniyachelovecheskogo-kapitala-rukovoditelraboty-k/

7. Симонович Н. Е., Киселева И. А. Проблемы социальной безопасности человека в современном обществе Национальные интересы: приоритеты и безопасность. 2013. № 44. С. 48-49.

8. Симонович Н. Е. Психология личности В информационном обществе В сборнике: Психология сознания: истоки и перспективы изучения Материалы XIV Международных чтений памяти Л. С. Выготского: в 2 томах. Министерство образования и науки Российской Федерации, ФГБОУ ВПО “Российский государственный гуманитарный университет" (РГГУ), Институт психологии им. Л. С. Выготского, Фонд Л. С. Выготского; Под редакцией В. Т. Кудрявцева.2013. С. 142-144.

9. Симонович Н. Н. Формирования человеческого капитала: психологические факторы, № 60-1, 18.02.2017, https://novainfo.ru/article/11369

10. Чистникова И.В. Социальнопсихологическое развитие человеческого капитала как фактор повышения производительности труда. https://cyberleninka.ru/article/n/sotsialnopsihologicheskoe-razvitiechelovecheskogo-kapitala-kak-faktorproizvoditelnosti-truda/viewer

11. Khakimov Erkin Tuychiyevich. Dynamics Of Moral Relations In Uzbekistan: Social And Philosophical Aspect. The American Journal of Social Science and Education Innovations, 2(12), 375-381.

12. Khakimov Erkin Tuychiyevich. SUBJECT OF INNOVATION ACTIVITY-DEFINING ELEMENT OF MODERNIZATION OF THE 
SOCIETY. EPRA International Journal of Research \& Development (IJRD) Vol. 5, Issue 7 July, 2020.

13. Erkin Khakimov. Education and Business Collaboration in Conditions of Transitional Economics: Philosophy of Changes. Canadian Social Science, 16(3), 46-49.

14. Bakhromovich, S. I. (2020). Effects of Objective and Subjective Factors to Develop Intellectual Culture of Youth. Canadian Social Science, 16(2), 55-59.

15. Сидаиков, И. Б. (2018). СОЦИАЛЬНОФИЛОСОФСКИЕ АСПЕКТЫ ФОРМИРОВАНИЯ ИНТЕЛЛЕКТУАЛЬНОЙ КУЛЬТУРЫ МОЛОДЁЖИ. Theoretical \& Applied Science, (1), 61-66.

16. Bakhromovich, S. I. (2020). Analysis Of Modern Approaches To Ensuring The Effectiveness Of Management In Higher Education Institutions. The American Journal of Social Science and Education Innovations, 2(12), 364-369.

17. Bakhromovich, S. I. (2018). Social and philisophical performance of making youth's intellectual culture. European science review, (7-8).

18. Bakhromovich, S. I. DEVELOPMENT TRENDS AND TRANSFORMATION PROCESSES IN ACADEMIC MOBILITY IN HIGHER EDUCATION IN UZBEKISTAN AND THE WORLD.

19. Mirzarahimov, B. (2019). The factor of good neighborhood and tourism development (Philosophical analysis). Scientific Bulletin of Namangan State University, 1(1), 140-145.

20. Mirzarakhimov, B. (2020). Tourism-is a modern means of aesthetic education. Вестник педагогики: наука и практика, (51), 135-136.
21. Мирзарахимов, Б. Х. (2019). КУЛЬТУРА ТУРИЗМА КАК СТРАТЕГИЯ РАЗВИТИЯ КНИГОВЕДЕНИЯ. In ПЕРСПЕКТИВНЫЕ ОБЛАСТИ РАЗВИТИЯ НАУКИ И ТЕХНОЛОГИЙ (рp. 57-58). 